
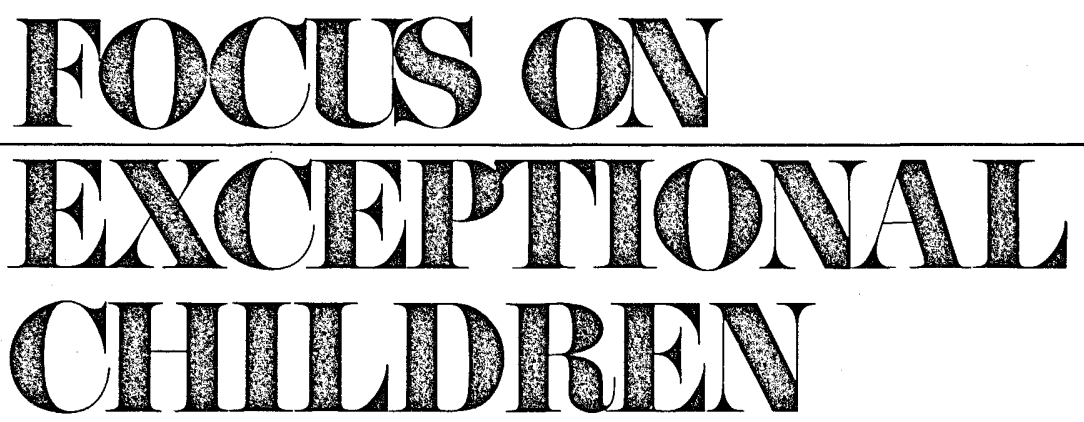

\title{
Written Language for Mildly Handicapped Students
}

\author{
Edward A. Polloway, James R. Patton, and Sandra B. Cohen
}

The ability to communicate in written form has frequently been referred to as the highest achievement in language for people in all modern cultures. Effective written communication requires application of conceptual and organizational skills in situations ranging from the concrete to the abstract. Unlike a more strictly defined skill area such as spelling, writing demands, foremost, a psychological rather than a mechanical commitment in order to produce excellence.

Written communication builds upon the language skills of speaking, listening, and reading. Ironically, perhaps for this very reason, writing has failed to receive its due from educational theorists, researchers, and practitioners. Thus, even though considered an honored and respected ability, it paradoxically has often been overlooked as an important curricular domain, and as a result, a high prevalence of poor writers can be found both throughout the grades and in adult society. Riemer (1969) emphasized the significance of writing for higher education, business, and various professions and decried the American educational system for failures in the pedagogy of writing. He stated:

\footnotetext{
American adults don't write because they are the victims of a system intensely determined to make them readers, not writers, and because there is no true and proper curriculum designed to develop writing. (p. 43)
}

Lack of curricular attention to writing has also been a particular problem in special education. The emphasis on teaching handicapped students to be good readers and efficient mathematicians has frequently left behind equally important concerns for the "second R."

Without question, all language domains are complex. This is certainly no less so for writing. As a curricular domain, writing includes the initial efforts of young children to scribble and spell their names, as well as the advanced compositional skills of the accomplished author. The breadth of written communication allows many avenues for theoretical and instructional approaches to develop. Within this broad spectrum, we have selected for discussion a singular component of writing 
skill development: the conceptual-expressive aspect of written language. Essentially the concern is for the ultimate goal of writing, which is effective communication. The more conceptual aspects of writing, however, can never be fully separated from tool subjects such as spelling and handwriting. Research and discussions on handwriting (Graham \& Miller, 1980) and spelling (Graham \& Miller, 1979) have led to the belief that writers can efficiently monitor written expression only when some degree of legibility is evident (Cohen \& Gerber, in press).

Hammill and Poplin (1978) specified the objectives of writing instruction as including the goals of:

1. teaching the minimal competencies required for success within the school curriculum;

2. teaching the abilities requisite for successful post-school adjustment; and

3. providing an opportunity for self-expression.

If these goals can be achieved, the student will have acquired not only a significant practical skill but also a vehicle for organizing and directing thought to further personal ideation. The close relationship between writing and thinking was succinctly stated by Loban, Ryan, and Squire (1969):

To write clearly, students must think clearly. To write competently, students must think competently. To write with power and imagination, students must think with power and imagination: think/write, write/think - these processes can not be

FOCUS ON EXCEPTIONAL CHILDREN (ISSN 0015-5IIX) (USPS 203-360) is published monthly except June, July, and August as a service to teachers, special educators, curriculum specialists, administrators, and those concerned with the special education of exceptional children. This journal is abstracted and indexed in Exceptional Child Education Resources, and is also available in microform from Xerox University Microfilms, Ann Arbor, Michigan. Subscription rates, $\$ 15.00$ per year. Copyright 1981, Love Publishing Company. All rights reserved. Reproduction in whole or part without written permission is prohibited. Printed in the United States of America. Second class postage is paid at Denver, Colorado. POSTMASTER: Send address changes to:

$$
\begin{aligned}
& \text { Love Publishing Company } \\
& \text { Executive and Editorial Office } \\
& 1777 \text { South Bellaire Street } \\
& \text { Denver, Colorado } 80222 \\
& \text { Telephone (303) } 757-2579
\end{aligned}
$$

\section{EDITORIAL BOARD}

Edward L. Meyen

University of Kansas
Glenn A. Vergason Georgia State University

Richard J. Whelan

University of Kansas Medical Center

Carolyn Acheson

Senior Editor
Stanley F. Love

Publisher disjoined. When a student has learned to write better, he has learned to think better. (p. 319)

In addressing the topic of written language and exceptional learners, our concern here is for those who are commonly referred to as mildly handicapped students identified as learning disabled (LD), mildly retarded (EMR), and emotionally (or behaviorally) disordered (ED). Categorical emphases, however, are of limited significance since in written language programming, as in other curricular areas, individual needs must predominate and group generalizations regarding teaching methodology are of questionable value. In terms of chronological ages, the population of greatest concern is that group placed under increasing demand for communication skill development by regular classroom requirements and post-school survival. For many mildly handicapped persons, acquiring a reasonable degree of facility in written language may contribute substantially to community self-sufficiency and independence, vocational flexibility, and success in higher education.

No longitudinal investigation of the written language abilities of mildly handicapped students has been reported that is comparable, for example, to the work of Loban (1963) with nonhandicapped children. Therefore, although texts frequently refer to the deficits of EMR, LD, and ED students within this domain, empirical data on the nature and specifications of these problems is quite limited. Among the studies that have been reported, the results are generally predictable. Myklebust (1973), for example, researched the writing output of four age groups of reading disabled students and found

STATEMENT OF OWNERSHIP, MANAGEMENT AND CIRCULATION

Date of Filing: September 30, 1981

Title of Publication: FOCUS ON EXCEPTIONAL CHILDREN

Frequency of Issue: Monthly except June, July and August

Location of Known Office of Publication: 1777 S. Bellaire St., Denver, CO 80222

Location of Headquarters of Publisher: 1777 S. Bellaire St., Denver, CO 80222

Name and Address of Publisher. Editor, and Managing Editor: Stanley F. Love, 1777 S. Bellaire St., Denver. CO 80222

Owner: Stanley F. Love

Extent and Nature of Circulation:

$\begin{array}{lcr} & \begin{array}{c}\text { Average No. Copies } \\ \text { Each Issue during } \\ \text { Preceding 12 months }\end{array} & \begin{array}{r}\text { Single issue } \\ \text { Nearest to } \\ \text { Filing Date }\end{array} \\ \begin{array}{l}\text { Total No. Copies Printed } \\ \text { Paid Circulation }\end{array} \quad 9,329 & 8,000 \\ \quad \text { Sales thru Dealers, etc. } & 0 & 0 \\ \quad \text { Mail Subscriptions } & 7,056 & 6,649 \\ \text { Total Paid Circulation } & 7,056 & 6,649 \\ \text { Free Distribution } & 300 & 300 \\ \text { Total Distribution } & 7,356 & 6,949 \\ \text { Office Use and Left Over } & 1,973 & 1,051 \\ \text { Total . } & 9,329 & 8,000\end{array}$


common deficiencies in linguistic output (evaluated in terms of total words used and number of sentences written), syntactical competence, and the ability to use abstractions.

A more recent study by Poplin, Gray, Larsen, Banikowski, and Mehring (1980) did provide an initial basis for considering the deficits of LD students. Comparing a group of disabled and nondisabled students at three grade levels (3-4, 5-6, and 7-8) across the five principal subtests of the Test of Written Language, they reported greater deficits in areas reflecting conventional aspects of grammar and spelling as contrasted with those more reflective of ideation and the conveyance of learning.

Also, Hermreck (1979) compared compositions of learning disabled and nonhandicapped students in several grades and found differentiated word totals. In fact, non-LD students wrote an average of 42 percent more words per composition than did their handicapped peers.

Deficits shown by some handicapped students in grammatical skills can be explained somewhat by the data reported by Deshler (1978). Specifically, disabled learners detected only one-third of the errors they made. On the basis of these data, one may justifiably assume that problem learners need strategies to monitor writing performance.

Despite the scarcity of research on conceptual and expressive writing deficits of handicapped students, clinical and anecdotal data certainly verify their prevalence. Wiig and Semel (1980), for example, stated that preadolescents and adolescents with language disabilities often have a series of specific difficulties that interfere with performance in decoding and encoding language. They suggested that common problems may be present in semantics (e.g., narrow word meanings, minimal semantic elaboration, and restricted variety in word use), syntax (e.g., limited use of complex sentences, tense and time markers), and memory (e.g., inefficiency in word retrieval and deficits in retention). These problems are especially significant for students as they face the written language demands at the upper elementary and secondary levels. Similarly, Davis (1975) characterized the writing of college students with learning disabilities as being: (a) rigid with limited variety in sentence patterns, word selection, and style; (b) poorly organized in controlling ideas and developing thoughts and arguments; (c) lacking in comparisons, elaborations, or conclusions.

To assist the practitioner in successfully planning and implementing appropriate instruction, it is important to understand the nature of the act of written communication and empirically and experientially supported techniques for remediation of writing deficits. This section describes instructional and general assessment principles, and the next section discusses approaches to remedial programming. Written language evaluation instruments are listed at the end of this article.

\section{A MODEL FOR WRITTEN LANGUAGE}

To approach the remediation of various written language skill deficits without an initial analysis of the nature and process of writing itself would be questionable pedagogical practice. Although for many mature writers, aspects of this process may be automatic or at least semi-automatic, students with difficulties in writing may evidence problems at a more conscious, functional level. Hall (1981) termed three stages of a writing task as pre-writing, writing, and post-writing. These are incorporated within Figure 1, a conceptual model of the written language process. It has been developed from the perspective of the learner/writer and therefore is concerned with input to the student, task demands on the student, and output by the student. The major components of the model have direct implications for basic instructional principles and remediation.

\section{Input}

This consideration refers to the provision of stimulation to the student. It summarizes the various ways the educational and home environment can be manipulated to influence the would-be writer. The basis for its consideration is simply, as Petty and Bowen (1967) noted, that "input must precede outgo." Without stimulation, we can not anticipate response. Through the verbalizations of others (as in speeches and lectures), opportunities to experience the environment through diverse means (e.g., field trips, athletics, classroom activities), encounters with reading, interpersonal interactions of a verbal or nonverbal nature, and continuous and varied auditory/visual stimuli (e.g., multi-media, television, radio, movies, charts, photographs, pictures), the student can develop both an interest in a given topic and the degree of familiarity or experience necessary for effective communication.

In considering input, teachers should examine: (a) students' educational backgrounds (e.g., previous teachers, experiences with writing; (b) how students spend their vacations, weekends, and so forth; (c) what books students have read; (d) what students talk about when they 
Figure 1

A Model of Written Language

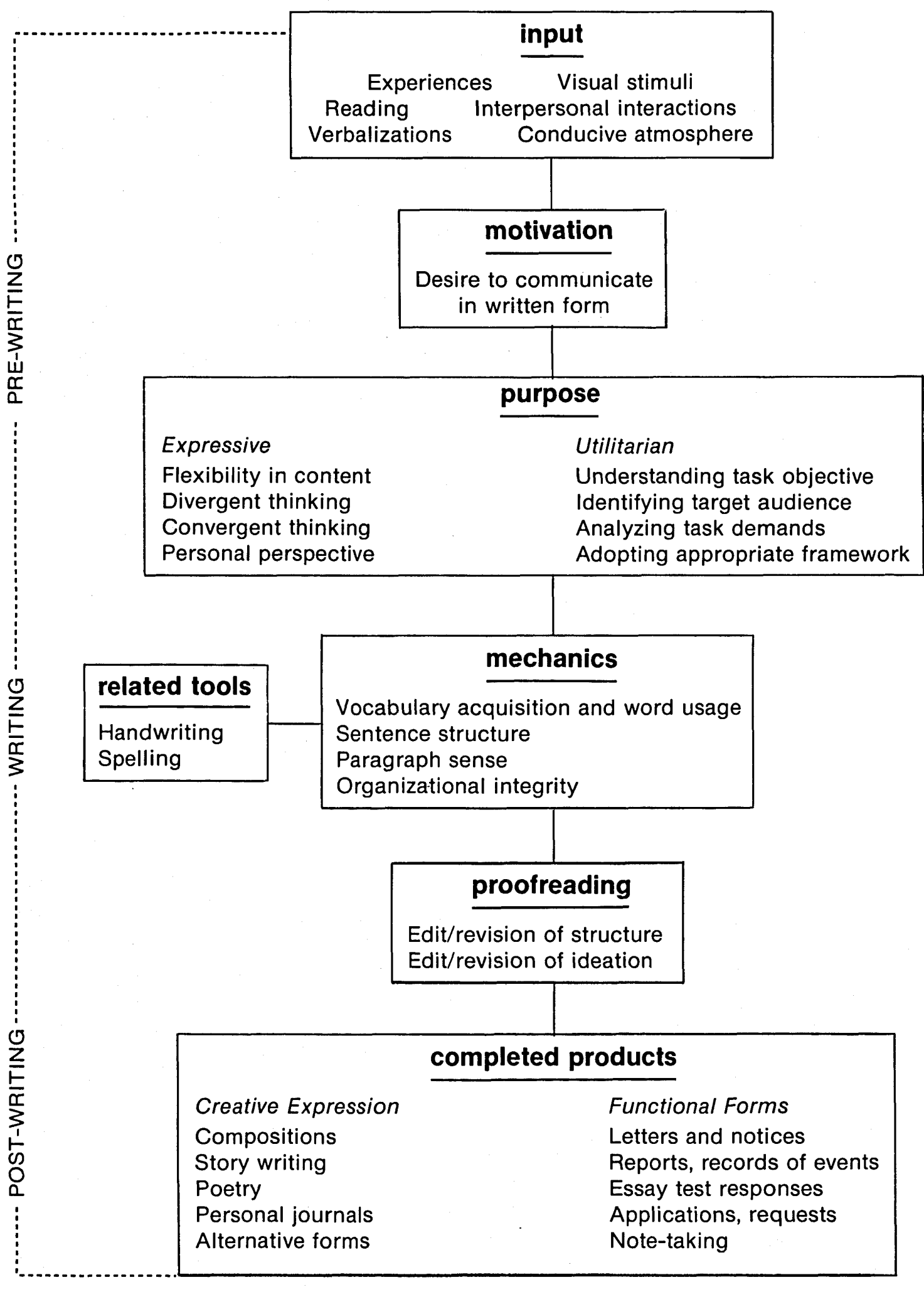


are at home with peers; and (e) an individual student's learning style or how he or she learns more efficiently.

\section{Motivation}

This aspect of written expression stems directly from the various forms of input. Students have to develop the felt need to communicate. Clearly, a poor attitude toward writing is among the most important considerations in instruction (Alley \& Deshler, 1979; Mercer \& Mercer, 1981; Smith, 1974). In addition to antecedent stimulants, this can be achieved through event consequences such as increased personal interaction and positive feedback.

Evaluative inquiries should include determining: (a) the value or importance of writing as students perceive it; (b) students' interests, as ascertained by administering interest inventories that explore educational, extracurricular, and community interests, as well as preferences in hobbies, books, movies, and the like; (c) career goals (to gain information that will be useful for pointing out the relevance of particular writing skills); and reinforcement preferences.

\section{Purpose}

Establishing purpose serves as the basis for organizing writing and creates an awareness of writing as a natural process of communication (Golden, 1980). For handicapped learners, two general purposes for writing can be identified: expressive and utilitarian. These represent variant forms of writing that are separated in this model to highlight their different objectives. Expressive or creative writing emphasizes the personal communication of experiences and thoughts in an original way, and utilitarian or functional writing conveys information in a more structured form, as with letters and reports (Mercer \& Mercer, 1981).

Despite this oversimplified distinction, the two purposes need not be oppositional. The two forms can be teamed to facilitate the acquisition of abilities (Cohen \& Plaskon, 1980). In addition, as noted by Petty and Bowen (1967), utilitarian writing can become more creative as it becomes more individualistic, novel, and unusual. Thus, although the instructor initially should differentiate between the two forms in assisting handicapped students to set purpose, the relationship between them ultimately may become far less disparate.

By helping the writer set and refine purpose, the teacher is encouraging students to be more attentive to the demands of the topic, to be more reflective of ways to achieve goals, and to become actively involved in each of the writing stages necessary for an acceptable product. These concerns - attention, reflection, and active learning - have frequently been identified as major deficiencies in the learning repertoire of mildly handicapped students (see, for example, Epstein, Hallahan, \& Kauffman, 1975; Ross, 1976; Torgeson, 1977; Wong, 1979).

In expressive writing, the specification of purpose entails several critical features. First, the writer must appreciate the inherent flexibility in selecting and developing content for the theme. Such an awareness stems directly from the open atmosphere of the classroom. Next, the ability to think in a divergent fashion must be tapped as the writer explores the specific ideas and topics of interest within the overall boundaries of the assignment. Convergent thinking then provides the vehicle for organization by narrowing the scope of the topic and allowing for the selection of relevant information. Finally, the constant input of a personal perspective ensures an eventual product that will be unique and original.

In utilitarian writing, the shift in focus dictates a parallel change in the writer's understanding regarding purpose. Understanding the task objective is requisite to further consideration. Clearly the writer must be able to appreciate the rationale behind, for example, a wellwritten letter of request or an autobiographical sketch as part of an application procedure. Second, the writer must have an awareness of the target audience so that the appropriateness of form can be matched to the characteristics of the reader(s). As Golden (1980) stated:

Since purposeful writing can not occur in a vacuum, writers are, in varying degrees, aware that someone will read their message or poem. (p. 758)

Although the audience is also a concern in creative expression, it is far more critical in functional writing.

Following from these initial points, an analysis of task demands then requires the writer to consider questions of length, specific conventions tied to a given product (e.g., the parts of a formal letter), and the possible need for any number of concerns such as persuasion, specificity in request, factual detail, and general overview. Finally, these aspects can provide a basis for selecting an appropriate framework, such as a list, an outline, or a narrative, that will best enhance the purpose of communication.

\section{Mechanics}

The mechanical aspects of writing are of varying importance depending upon the nature of a specific 
assignment or task. The specific items outlined in Figure 1 summarize the basic mechanics common to semantically, syntactically, and organizationally sound written products. Each of these categories subsumes a host of subskills related to the development of writing competence.

Vocabulary acquisition and word usage are the basic semantic foundations for writing. Two instructional goals predominate in vocabulary acquisition: to encourage students to make use of the variety of words they already possess in their oral receptive and expressive lexicon, and to help students learn and use new words particularly as they aid in the written discussion of a given topic. Teachers must be alert to spelling deficits as they can contaminate written vocabulary; and students should be aided in developing compensatory means to facilitate the use of specific words.

Word usage is concerned with the appropriate construction of meaningful phrases and sentences based on selections from a student's vocabulary. The key instructional objectives should encompass the needs to: (a) curtail the redundant use of common words; (b) increase the use of descriptive words; (c) alternate synonyms for common thoughts in a passage; (d) select words that most precisely fit the meaning of the sentence; (e) avoid awkward word combinations; and (f) maintain consistency with the purpose of the writing task and the intended audience.

Sentence structure, used here as a generic term referring to the range of specific grammatical skills, is allied with the major syntactical concerns within sentences including appropriate verb tense, noun-verb agreement, noun-pronoun agreement, correct forms for other morphological structures, capitalization, and punctuation. In addition, the need for variety in the forms and functions used should be emphasized. Fragments and run-ons should be avoided, with form varying from simple to compound and complex. The writing function should emphasize the use of a blend of declarative, interrogative, imperative, and exclamatory sentences.

Paragraph sense refers to the transition in writing from syntactically accurate sentences to well-written compositions or reports. It taps the student's ability to organize thoughts in a coherent fashion that conveys a central message to the reader. In a developmental sense, the following sequential abilities must be learned: (a) paragraphs must express a single concept or main idea; (b) initial, topical sentences should provide a lead-in for the reader; (c) subsequent sentences should provide further support to the concept being discussed; and (d) final sentences in longer paragraphs should serve a summary or transitional function.
Organizational integrity is concerned with the overall product. The focus is on how the mechanics and the writing style manage to achieve the identified purposes. Students must be alert to: (a) the manner in which ideas are sequenced; (b) consistency between the discussion and conclusions; (c) clarity of the message communicated; (d) retention of personal style (when appropriate); and (e) relevance of detail to the stated purpose.

\section{Proofreading}

Classified in the conceptual model as an essential aspect of the post-writing stage, proofreading basically entails the process of editing and revising for both content and structure. Frequently, the importance of this concern may not be apparent to handicapped learners, because of an emphasis on task completion. In other instances, problem learners may associate editing with a failure syndrome, as a result of over-correction of previous writing assignments. Lovitt (1975) noted that many writers consider revision as simply changing punctuation marks and misspellings. To move beyond this limited concept of proofreading, students must be taught specific steps to follow in reviewing their own written work samples.

An emphasis on proofreading should also offer far greater advantages to the writer than the repetitive completion of worksheets. As Poplin et al. (1980) noted, the benefits of this emphasis would include the more meaningful nature of the exercise because of students' greater familiarity with the words and ideas they created and the increased potential for generalization of skills.

To determine if students are able to effectively use proofreading and editing skills, evaluation should focus on the following questions: (a) Can students identify specific mechanical errors within a sentence or a paragraph? (b) Can they identify organizational and ideational problems within a composition? (c) Can they effectively use strategies for proofreading (e.g., a sequential list of self-check statements)?; (d) Can they evaluate whether the objectives or purposes of the completed written draft have been met? and (e) Can they transfer these skills from contrived exercises to actual written assignments?

\section{Completed Products}

After the revisions of the post-writing stage, students will have developed a completed product. Returning to the distinction between expressive and utilitarian purposes, these products can be classified to a certain 
extent as creative or functional. Creativity is typically most evident in original compositions, poetry, personal journals, and other vehicles for individual ideation. Functional products include social and business letters, class reports, minutes of meetings and other records of events, various forms of applications, and essay test responses that allow some flexibility in writing output. Note-taking, also an important functional skill, dictates its own mechanics and is necessary for survival in the regular classroom. The need for accurate, useful notes becomes increasingly vital to students as they enter the upper levels of school, where the lecture format is the presentation of choice in many classes.

Writing achievement in one form (either expressive or utilitarian) does not necessarily imply parallel performance in the other, although much transference occurs. Thus, instructional attention must be given specifically to each type of writing, while planning for and expecting a certain level of generalization.

\section{INSTRUCTIONAL STRATEGIES}

A written language methodology and curriculum designed distinctly for handicapped students is not being proposed in this discussion. Rather, as Polloway and Smith (1982) have stated:

\begin{abstract}
In general, teachers will need to organize their curriculum specially around regular class language activities to the extent that students participate in general education programs. Regardless of the situation, however, methods of teaching written expression to exceptional children more often reflect close ties to, and adaptations of, general curriculum than any other language area (Haring \& Bateman, 1977; Kirk \& Johnson, 1951; Wallace \& McLoughlin, 1976). (p. 350)
\end{abstract}

Therefore the teacher's task is to begin from a foundation of sound instructional strategies for written communication and make modifications that will be effective for individual needs of handicapped learners.

\section{Input}

The basis for beginning writing and written language instruction is stimulation. Students must be provided with input that fosters the formulation of their own ideas. Teachers should capitalize on the other language domains to enhance this process. For example, opportunities to talk about personal experiences and listen to others' encounters can provide a basis for writing purpose and content. Reading interesting stories can also develop the student's desire to communicate feelings about the ideas expressed by the author (Polloway \&
Smith, 1982). Dawson and Zollinger (1957) outlined an instructional language experience-type approach that provides a means of integrating the various language arts.

Petty and Bowen (1967) have emphasized the importance of ensuring an appropriate climate for writing. They noted several aspects of such a climate that would provide an atmosphere conducive for writing: the attitudes and personality of the teacher (characterized by an open and friendly rather than a rigid demeanor), the establishment of frequent opportunities for writing, and students' awareness of the potential outlets for their work. Handicapped students in particular need to develop a sense that writing is an enjoyable rather than a punitive activity. The above points can be summarized as the need for writing stimulation within the context of a positive, supportive atmosphere.

\section{Motivation}

Closely tied to the discussion of input is the topic of motivation. The preeminent concern is the development of intention to communicate, the desire to share one's thoughts with a given readership. Without attention to motivation, an individual's writing will likely reflect only minimal personal perspective and creativity and will fail to realize the basic goals of functional writing tasks.

Ideally, motivation should be a function of one's own internal needs to communicate and to express feelings, ideas, and needs. As Tway (1975) noted in reference to nonhandicapped children: "No one can really motivate anyone else to write; motivation must come from within. Teachers can only stimulate" (p. 193). Tway also suggested that motivation could best be developed by showing a basic respect for a student's expression, by establishing real purpose in writing, by endowing writing with a special sense of importance and enjoyment, and by ensuring the writer that a specific goal is in sight.

In the case of exceptional learners, however, motivational problems are often intensified because of the failure set that many students have acquired through previous writing experiences. Alley and Deshler (1979) emphasized this point by noting that the feelings of students toward writing should be the first consideration of teachers. As Lerner (1981) stated, children who have experienced a dearth of success:

... soon learn to beat the game by limiting their writing vocabulary to words they know how to spell, by keeping their sentences simple, by avoiding complex and creative ideas, and by keeping their compositions short. (p. 344) 
Given this general tendency of some writers, Brigham, Graubard, and Stans (1972) questioned the basic assumption that “... writing flows from the writer" (p. 442) and that emphasis must be placed in building motivation just through stimulation. The option they proposed, in one of the initial efforts of applied behavior analysts in this domain, was to identify a series of objective aspects of writing, place reinforcement contingencies on them, and thus improve compositional skills through the sequential reinforcement of specific skills. The ABA methodology and results of this study and related ones are further discussed in succeeding sections.

Based on the valid identification of students' interests, structuring a writing program on these interests seems justifiable, keeping in mind that what appeals to some students may not appeal to all their classmates. If teachers truly are concerned about individualizing the programs of their students, capitalizing on students' interests makes good pedagogical sense.

\section{Purposeful Writing}

In their list of basic principles for improving writing ability, Otto, McMenemy, and Smith (1973) noted that “... writing is always done for a particular purpose and a particular audience, both of which the writer should be aware of at all times" (p. 390). Consistent with this statement, students must come to realize the essential reason for the writing tasks in which they are engaged, whether they are flexible assignments with an emphasis on self-expression or highly structured tasks with an emphasis on adopting a particular form.

Initial instruction with beginning writers can successfully help them set purpose and complete instructional exercises designed to emphasize task objectives. Short, specific assignments are valuable for sharply defining the student's task and, therefore, enabling a focus on the purpose of the assignment. For example, exercises with a creative purpose could include writing a paragraph on the descriptive properties of an interesting classroom object, on the qualities of friendship, on one's favorite time of the day, or on a particular scene from a favorite movie. Utilitarian exercises could include composing an invitation to a party, an announcement of a school movie, a covert note to a friend, a brief article for the school newspaper, or a postcard to be sent to a relative.

The importance of short assignments when students are first beginning to write can not be overstated. By presenting child ren with lengthy tasks or by setting aside an inordinate amount of time for them to write, the teacher may inadvertently create an association in the child's mind between writing and boredom, thus generating general disinterest and destroying purpose. A brief period of 15-20 minutes should be sufficient (Polloway \& Smith, 1982).

Setting purpose continues to have importance for advanced writers as well. A direct instructional approach to writing at this point should emphasize the specific steps listed in Figure 1, initially with the teacher leading the student through them (via visual and verbal prompts) and subsequently with the student working independently (self-instruction). For expressive writing, students should be encouraged to ask themselves these types of questions:

What interests me most about this topic?

What information do I know about this topic?

What else do I need to learn about it?

How can this information be related?

How can it best be organized?

What are my personal opinions about the subject?

How can I convey my personal feelings in my writing?

For utilitarian writing, students should consider these questions:

What is my objective in this task?

Who am I writing for? What do they know about this topic?

What do they want to know?

How can I make sure I convey the necessary and correct information?

Do I need to do research on the topic to be familiar with it?

How should I arrange and organize my writing to be most effective in meeting my objective?

\section{Mechanics}

The discussion on written mechanics focuses on the areas of vocabulary development and structural skills (e.g., sentence and paragraph sense and overall organization). Inherent in this framework are the specific writing craft skills noted in Figure 1. The semantic concerns related to increasing vocabulary and the mechanical concerns related to writing form must both be given instructional consideration. 


\section{Vocabulary}

A key concern in enhancing written communication skills is to increase the size of writing vocabulary and to increase the frequency with which these new words are used. The basis for instruction is to expose students to a multitude of verbal forms and then assist them in incorporating the words into their compositions. Specific objectives should include acquiring a store of synonyms for commonly used words, developing a familiarity with a variety of descriptive words, and using unusual words and original phrases as alternatives to more typical lexical options.

Teachers should be aware that many otherwise capable students may tend to avoid using words they can not spell, thus reducing the quality of their writing. Only when they can be convinced to not worry about spelling and concentrate on ideas can a true appreciation of their abilities be obtained (Johnson \& Myklebust, 1967). Similarly, when working with students for whom English is a second language, the primary concern should be with qualitative aspects rather than with correct spelling.

Cohen and Plaskon (1980) have stressed that mildly handicapped students should develop a vocabulary that can be used accurately: "Although the objective is to expand the child's facility with words, it must not be gained at the expense of writing fluency. A functional goal of providing [them] with word skills which allow them to successfully manipulate a limited core of words is advisable" (p. 295). They therefore suggested teaching word clusters that can center on topical themes. The clusters they listed included words for naming and describing common actions, personal attributes, and time, as well as facility with use of prefixes, suffixes, synonyms, and common idiomatic expressions.

A host of instructional exercises can be developed to assist in building vocabulary. For example, Van Allen (1976) suggested the use of a word wall that can be devoted to lists of words that might be helpful to students in writing. The list could include high frequency words, common descriptors, words of the senses, and specialized words tied to holidays or to specific units being studied. It could also be modified and individualized by developing a notebook of words for each student.

For individual writing assignments, the entire class could initially generate a list of key words to be written on the board. In this way, the conceptual break required to select and revisualize specific words could be avoided, and at the same time students would be provided practice in use of these words.
Several studies have reported on the value of reinforcement contingencies on vocabulary development. Maloney and Hopkins (1973) reported that points awarded to students in grades 4-6 contingent on the number of different objectives and action verbs used and the variant ways that sentences were begun enhanced these three aspects of composition and also resulted in the submission of papers subjectively rated as more creative by blind reviewers. Glover and Gary (1976) indicated that students' writing could be improved by developing vocabulary usage through the identification of "unusual uses" for a variety of nouns. Four measures of creativity (fluency, flexibility, elaboration, and originality) improved as a result of applying this technique. Kraetsch (1981) reported data on a single-subject design study indicating that oral instructions to a student to write "as many words and ideas as you can" had a significant effect on written output as measured by the quantity and diversification of words and the quantity of sentences produced. In all three studies, vocabulary was shown to improve, along with other aspects of writing, through reinforcement strategies.

\section{Structure}

The most significant question in teaching structural skills is how to build the appropriate skills without stifling students' interest in using written means for expression and communication. Sink (1975) contrasted two approaches to this question: the teach-write and the write-teach approaches. The former, representing the traditional pedagogy in composition, emphasizes instruction in skills as a basis for successful written expression, and, therefore, stresses the mechanical act of writing and attention to structure as the initial basis for writing. The latter is more concerned with ideas than form and, thus, initially emphasizes writing as a personal act that later can be shaped to acceptable grammatical structure.

A substantial body of related research has been reported with nonhandicapped students. Sherwin (1969), in his review of 50 years of research on the relationship between formal instruction in grammar and skill in writing, concluded that this type of instruction "... is an inefficient and ineffective way to help students achieve proficiency in writing" (p. 135). He cited a 1962 dissertation by Harris, deemed to be the most methodologically sound of the research reviewed, which concluded that such an approach may have a relatively harmful effect on the correctness of children's writing. Although Sherwin (1969) also concluded that writing 
alone does not teach writing, he summarized his review by noting that the most important features of instruction are "... motivation, selective criticism, discussion, practical explanation, and revision." (p. 168)

Definitive research with exceptional learners on this question has not yet been reported, but the write-teach approach has received more widespread support. Cohen and Plaskon (1980), for example, encouraged the use of spontaneous daily written expression opportunities as a basis for instruction in conventional skills. In a similar vein, Poplin et al. (1980) concluded from the limited data relative to this question:

Until otherwise proven, meaningful experiences with immediate, reasonable, and knowledgeable feedback still seem to offer the most effective method of improving mechanical, conventional knowledge of the writing process without interfering with and stifling the all-important ability to "get across" in writing what the student intends to communicate. (p. 52)

Given the limited support for the traditional approach to teaching grammar, the most appropriate instructional approach would appear to be one that provides feedback on a small number of selected structural errors in a given assignment. Errors to be corrected should be chosen based on their value to the student's communicative efforts. In addition, assignments should be evaluated in terms of their consistency with the student's oral language abilities. This can give the writer a basis for error awareness, which generally must precede accurate transcription. This awareness can be achieved by leading through a series of tasks requiring students to initially select the grammatically accurate sentence from several choices and eventually to identify specific errors within a sentence or paragraph. "Listening" for errors then becomes the basis for proofreading.

The value of feedback mechanisms on a student's writing has been documented in a variety of research studies. For example, the use of these mechanisms tied to structural skills was reported to be effective by Hansen and Lovitt (1973, cited by Hansen, 1978). They indicated that feed back on mechanics was more effective than was feedback on content in influencing both mechanics and content in a positive way.

Strategies designed to increase fluency have also been found to have a positive effect on structure (Brigham, Graubard, \& Stans, 1972; Van Houten, Morrison, Jarvis, \& MacDonald, 1974). Van Houten and his colleagues reported that feedback on the number of words written, accompanied by the posting of highest scores and instruction to exceed these scores, resulted in a doubling of the rate of words written in addition to an increase in the mechanical aspects of the compositions of second and fifth graders.
The most important focus within the mechanics of written language should be the sentence. By stressing well-developed sentences, teachers will be training handicapped students to think clearly and then to express themselves in complete thoughts in order to successfully communicate. Many handicapped students may rely on simple, repetitive, "safe" sentence structures, resulting in less fluent writing products. Others may experiment unsuccessfully with variety and be identified as producing awkward constructions (Hall, 1981). For either of these two sub-groups of poor writers, the instructional focus must be on teaching students to expand sentences within acceptable structural patterns. Several approaches to sentence expansion have been developed. Teachers should select a particular strategy based upon: (a) understanding the technique; (b) student needs; and (c) student language abilities.

Fennimore (1980) reported on instructional activities developed to facilitate sentence understanding and variety. She referred to these as sentence extension activities since the basic premise of the instruction was to enhance students' oral and then written sentences by enlarging the repertoire of words and forms available to them. For example, the sentence, "The boy ran" was extended by having the class identify lists of alternatives to boy and ran, adverb and adjective modifiers within the subject, modifiers of the verb, prepositional phrases to indicate where the boy ran, and so forth. This type of exercise can then become incorporated into compositional efforts that may stem from the original brief sentence form.

Sentence expansion or extension is the basis for the Phelps Sentence Guide Program (Phelps-Teraski \& Phelps, 1980). This systematic program involves a structured questioning process to which students respond in complete sentences. Logical extensions would then include instruction on nouns (e.g., Who did it?), verbs (e.g., What was done?), descriptors (e.g., What kind?), and objects (e.g., To what? For what?). By combining oral and written language, these sub-skills and other related ones can be taught within the context of the meaning of a sentence in lieu of being presented as specific semi-isolated items in a grammar instructional sequence.

\section{Paragraph Sense}

As noted earlier, paragraph sense builds from a student's competence in using basic paragraph components in a sequential and logical manner. As Otto, 
McMenemy, and Smith (1973) stated, "The most important concept for students to attain relative to paragraph development is that written communication is essentially a matter of making assertions and elaborating upon them" (p. 394). Therefore, specific teaching techniques should be adapted that assist students in stating their basic premises and then expanding their thoughts in an organized fashion.

To develop good paragraphing skills, students should be provided exercises on sequencing sentences that they can read without difficulty, as well as feedback on their own efforts. Again, the value of short assignments as a basis for such writing should be noted. Particularly in the case of students who have limited ability to develop lengthy, creative pieces, emphasis should be placed on consistent usage of simple rules for paragraph building within the context of functional tasks.

\section{Organizational Integrity}

The concept of organizational integrity refers to the overall sequence, clarity, and flow of writing beyond the paragraph level. Essentially, it is the final concern of the writer and the one that relates most closely to the setting of purpose during the pre-writing period. Within the written language model presented in this article, it serves as the basis for pulling together the objectives established before writing, with the mechanics utilized during the composition stage as a basis for the reviewing/editing process of post-writing. Therefore, it is most closely tied to the process of proofreading.

\section{Proofreading}

Proofreading is a critical skill upon which the quality of a finished product hinges, particularly when teachers are using the write-teach approach. To expect that most students will automatically edit and revise their work would be naive. As noted earlier, many exceptional students may come to view proofreading as an aversive rather than a positive process. Even those who are willing to revise must develop that ability; they must be shown how to proofread (Hillerich, 1979). The teacher's role, therefore, is one of modeling the specific techniques inherent in the proofreading process and delineating its advantages to the finished product.

The instructional goal is to have students learn the basic steps necessary to revise their writing and to later apply them independently. The questions listed below, incorporating suggestions by Dankowski (1966) and Burns (1980), provide an outline of self-evaluation procedures for writers to follow:
1. Does each sentence make sense?

2. Is every word spelled correctly?

3. Are all punctuation marks used correctly? Are any needed marks omitted?

4. Are all words capitalized that should be?

5. Have I used descriptive words and phrases to express my ideas?

6. Are any of the points I made vague and in need of clarification?

7. Are there more specific, precise ways to say anything in my paper?

8. Overall, is the paper organized in a clear way to make the reader's job an easy one?

9. Have 1 met the objectives I set for the paper?

10. Have I chosen a good title (when applicable)?

The entire proofreading process may be too involved for students with writing difficulties to tackle at one time. Therefore, although complete evaluation would require consideration of all aspects, one or two should be selected for a given assignment until students refine both their writing and editing skills. As time and skill development progress, more of the proofing guides can be added.

Editing and revision are generally considered to take place after writing, but they also occur at times during the writing process. Frequent conceptual breaks in midsentence or mid-paragraph (such as to check spelling), however, should be discouraged, to minimize interference with ideation.

Organizing proofreading instructional exercises in the classroom can be done in a variety of ways. One effective technique to help students develop an initial orientation toward proofreading is to have them practice verbalizing the various steps. Consistent with this approach, Hansen (1978) suggested that students work on the editing process by reading their stories aloud to the teacher during individual conferences, to learn to listen for inconsistencies.

\section{Completed Products}

Some considerations unique to specific types of written products should be stated. For simplicity, these are discussed under the two major areas of creative expression and functional form.

\section{Creative Expression}

Development of ideation in written compositions and related products has unique significance to exceptional 
learners. As Polloway and Smith (1982) stated concerning this expressive component of written language:

\begin{abstract}
Although instruction often centers on teaching skills and developing cognitive abilities, it would be self-limiting to overlook the affective side of written composition - its ability to serve as a vehicle for thought and ideas that handicapped students might otherwise withhold. The potential gains that adolescents with learning, emotional, or behavioral problems can achieve are especially noteworthy. Therefore, instruction in this area and the subsequent development of skills can be both a means as well as an end in itself. (p. 342)
\end{abstract}

A major objective for teachers of mildly handicapped learners, then, should be to provide ample opportunity for expressive writing.

An emphasis on creative expression in writing deemphasizes overcorrection regarding mechanical aspects. Creative writing favors the content over the craft. Tiedt (1975) noted that teachers should appreciate the ideas expressed reasonably coherently by writers rather than focusing on omissions, misspellings, poor handwriting, or missing punctuation marks. She stressed the need to be most concerned with the positive aspects of the student's writing. If, instead, students learn that how they write is more valued than what they write, the result will likely interfere with the expressive and communicative process (Golden, 1980).

Johnson and Myklebust (1967) provided an excellent outline of a progression of ideation reflected in the varying content of students' products. Basically, their idea sequence follows from the concrete to the abstract. The first stage, concrete-descriptive, emphasizes the use of a simple descriptive sentence or a series of such sentences about common things in the child's environment (e.g., The girl is running to the store.). The second stage, concrete-imaginative, stresses inferences from some stimulus or experience. In this stage, students would be encouraged to draw generalizations, to imagine what is happening, and to then respond accordingly.

A shift in emphasis to abstractions characterizes the other two stages in the Johnson and Myklebust progression. The third level, abstract-descriptive, places greater stress on the concepts of times and sequence, with students urged to write stories with logical order, appropriate transitions, and the development of plot and characters. The final level, abstract-imaginative, is based on open-ended types of questions and propositions upon which students base their perceptions. Stylistic improvements such as figures of speech can be incorporated, too, at this stage.

Given a logical progression through which to lead children in writing, teachers can enhance ideation and productivity using the basic strategies discussed earlier under "Input" and "Motivation." In addition, teachers should have access to a variety of appropriate topics for compositions to instill interest and stimulate thinking. The reader is referred to books by Carlson (1970), Petty and Bowen (1967), and Polloway and Smith (1982) for suggestions. The value of contingencies placed on writing (as noted earlier) to yield creativity should also be considered.

Many other vehicles are available to the teacher for encouraging the student's expression. Examples include story-writing, poetry, and developing diaries or journals as independent writing activities.

Story writing can take on a variety of forms as a tool to motivate composition writing. An interesting approach (Collins, 1980), called class-mating, was developed to increase writing motivation in secondary students by having them develop stories to be read by elementary-aged children. Collins indicated that this strategy provided an audience for writing and enabled teachers to emphasize the need for grammatical accuracy in standard English for "published" work.

Teachers often shy away from teaching poetry, because of the language limitations of their students. As Rich and Nedboy (1977) noted in discussing the creations of young adolescents, however, the question is not whether it is truly poetry since the mark of success is not in the creation of a literary product ". . . but in the use of poetry writing as a vehicle for reaching a variety of other goals" (p. 94). Similarly, Nathanson, Cynamon, \& Lehman (1976) commented:

Teaching poetry to exceptional children of any chronological age, of any intellectual level, or of any handicapping condition enables the classroom teacher to expand his or her own potential beyond the purely functional approach to curriculum development. (p. 90)

Personal diaries or journals have been a popular instructional adjunct ever since the report by Fader and McNeill (1968) confirmed the value of such an approach. This technique is based on having the student write for a designated length of time or a designated number of pages without teacher evaluation. The student selects the topics, which range from simple copying exercises to truly creative expression.

In a related vein, Tsimbos (1980) described how journals could be used with children for whom English is a second language. In this program, students were required to write a minimum number of words per day without regard for correctness. The teacher then read these and gave responses limited to specific English vocabulary words or ideas that would assist the student in better expression. Essentially, the program provided a 
basis for communication in English between student and teacher.

\section{Functional Forms}

Utilitarian writing dictates greater concern for structure than does creative expression but nevertheless should provide an opportunity for a personalized form of communication. The most common types of functional writing include letters, notices, invitations, reports, and applications. Each of these carries with it a given format and, thus, specific procedures for instruction. In each case, the initial emphasis on short, specific assignments should be adhered to, to promote appropriate production.

Two other areas of functional writing warrant special attention because of their particular importance to adolescents with writing difficulties: note-taking and essay exam writing. These skills become more important as students enter higher grades. Although both areas relate more closely to study skills than to written expression, they demand attention because they are typically neglected in formal instruction.

Note-taking. For just a moment, consider how you developed your own personal note-taking skills whether you created your own system, were given formal instruction, or viewed someone else's format and adopted it. Regardless of which of the above mechanisms might apply, at some time in all students' educational careers, they must become "note-takers." School failure or success may depend in part on whether a student becomes efficient or remains inefficient at this task.

Note-taking skills become necessary, for example, when listening to a speaker, watching a film, or reading a textbook. Alley and Deshler (1979) have categorized note-taking into three specific skill areas:

(1) outlining - the sequential arrangement of main features of a book, a subject, or a lecture;

(2) formal notetaking - the concise but comprehensive statement of essential matter read or heard; and

(3) informal notetaking - the brief, spontaneous recording of material to assist the memory or for subsequent reference or development. (p. 129)

The value of these skills lies in the fact that they greatly assist students organizationally, an important concern for many mildly handicapped students. The following list of suggestions offers a few ideas for teachers in helping students become better note-takers:
1. Preparation

a. Make sure all necessary materials are ready. This may include specially prepared paper (e.g., with a specific note-taking format).

b. If available, obtain ahead of time a skeletal outline of the lecture from the instructor.

2. Instruction

a. Give practice at taking notes.

b. Provide feedback on the quality and quantity of notes.

c. Teach the use of various shorthand conventions, abbreviations, or personal codes (e.g., $\bar{s}$ for without, $\bar{c}$ for with).

d. Emphasize that students are not to write down every word.

e. Provide training in how to recognize key words (e.g., "most important") or key behaviors (e.g., writing a phrase on the board) of instructors.

3. Aids

a. Have students use small pocket-size notebooks for a variety of reasons (e.g., "things to do today," assignments, questions to ask the instructor).

b. Encourage the taping of lectures in order to augment poor in-class note-taking skills.

c. Have students check their notes with those of others.

Essay Test-taking. Although techniques are available for maximizing students' performance on various types of tests, our attention is directed to essay situations that require written expressive skills to a greater extent than other formats. To students with problems in written language, the essay test can be devastating. The conventions of writing already discussed in this article still apply, but a few additional suggestions are offered:

1. Nurture a positive, success-oriented attitude toward the impending test situation.

2. Encourage students to use their time effectively, both prior to the test when preparing and during the test itself.

3. Have students perform triage on the essay questions - responding first to the questions to which they know the answers, and postponing the more difficult ones.

4. Instruct students on recognizing and understanding certain "task-demand" clue words such as compare, elaborate, and list.

5. Encourage students to outline the answer to each essay question before giving any written response. This helps not only the testee but the examiner as well. 
6. Incorporate the use of mnemonic aids in test preparation and test taking (for example, the taxonomic breakdown of Kingdom, Phylum, Class, Order, Genus, Species may be remembered more readily through the mnemonic phrase, "King Peter Comes Of Good Stock").

7. Use alternative means of evaluation with students who encounter great difficulty with written form, as their performance on essay-type tests may not accurately reflect their competence or knowledge.

\section{CONCLUDING REMARKS}

The problems faced by exceptional children, adolescents, and adults who have written language difficulties have only relatively recently begun to receive the type of intensive scrutiny that is needed. The discussion here has highlighted some of the key results of recent work in this area. Several additional areas warrant the attention of practitioners and researchers interested in enhancing the professional state-of-the-art in written language instruction for the handicapped. These areas include: clarification of writing characteristics typically found to be strengths and weaknesses within sub-groups of the mildly handicapped population; refinement of informal assessment inventories that have a primary focus on the various facets of written expression; resolution of the relative merits of reinforcement strategies versus stimulation exercises as a basis for motivating variant groups of handicapped learners; and development of detailed, direct instructional systems for teaching writing that parallel recent efforts, for example, in reading and arithmetic.

\section{REFERENCES}

Alley, G., \& Deshler, D. Teaching the learning disabled adolescent: Strategies and methods. Denver, CO: Love Publishing Co., 1979.

Bailey, E. J. Academic activities for adolescents with learning disabilities. Evergreen, CO: Learning Pathways, 1975.

Brigham, T., Graubard, P., \& Stans, A. Analysis of the effects of sequential reinforcement contingencies on aspects of composition. Journal of Applied Behavior Analysis, 1972, 5, 421-428.

Burns, P. C. Assessment and correction of language arts difficulties. Columbus, $\mathrm{OH}$ : Charles E. Merrill, 1980.

Carlson, R. K. Writing aids through the grades. New York: Teacher's College Press, 1970.

Cohen, S. B., \& Gerber, M. M. Assessment of written expression and handwriting skills. In A. F. Rotatori \& R. Fox (Eds.), Assessment for regular and special education teachers: A case study approach. Baltimore: University Park Press, in press.

Cohen, S. B., \& Plaskon, S. P. Language arts for the mildly, handicapped. Columbus, OH: Charles E. Merrill, 1980.
Collins, J. L. Class-mating: A strategy for teaching writing in urban schools. In G. Stanford (Ed.), Reading with differences. Urbana, IL: National Council of Teachers of English, 1980.

Dankowski, C. E. Each pupil has his own editor. Elementary School Journal, 1966, 66, 249-253.

Davis, V. I. Including the language learning disabled student in the college English class. Paper presented at 26th Annual Meeting of the Conference on College Composition, St. Louis, 1975. (ERIC Document Reproduction Service No. ED 114 823)

Dawson, M. A., \& Zollinger, M. Guiding language learning. Yonkerson-Hudson, NY: World Book Co., 1957.

Deshler, D. O. Psychoeducational aspects of learning-disabled adolescents. In L. Mann, L. Goodman, \& J. L. Wiederholt (Eds.), Teaching the learning disabled adolescent. Boston: HoughtonMifflin, 1978.

Epstein, M. H., Hallahan, D. P., \& Kauffman, J. M. Implications of the reflectivity-impulsivity dimension for special education. Journal of Special Education, 1975, 9, 11-25.

Fader, O. N., \& McNeill, E. B. Hooked on books: Program and proof. New York: Berkeley Publishing, 1968.

Fennimore, F. Attaining sentence verve with sentence extension. In G. Stanford (Ed.), Dealing with differences. Urbana, IL: National Council of Teachers of English, 1980.

Glover, J., \& Gary, A. L. Procedures to increase some aspects of creativity. Journal of Applied Behavior Analysis, 1976, 8, 79-84.

Golden, J. M. The writer's side: Writing for a purpose and an audience. Language Arts, 1980, 57, 756-762.

Graham, S., \& Miller, L. Spelling research and practice: A unified approach. Focus on Exceptional Children, 1979, 12 (2), 1-16.

Graham, S., \& Miller, L. Handwriting research and practice: A unified approach. Focus on Exceptional Children, 1980, I3 (2), $1-16$.

Hall, J. K. Evaluating and improving written expression: A practical guide for teachers. Boston: Allyn \& Bacon, 1981.

Hammill, D. D., Brown, V. L., Larsen, S. C., \& Wiederholt, J. L. Test of adolescent language. Austin, TX: Pro-Ed, 1980.

Hammill, D. D., \& Poplin, M. Problems in writing. In D. D. Hammill \& N. R. Bartel (Eds.), Teaching children with learning and hehavior problems. Boston: Allyn \& Bacon, 1978.

Hansen, C. L. Writing skills. In N. G. Haring, T. C. Lovitt, M. D. Eaton, \& C. L. Hansen (Eds.), The fourth R: Research in the classroom. Columbus, $\mathrm{OH}$ : Charles E. Merrill, 1978.

Haring. N. G., \& Bateman, B. Teaching the learning disabled child. Englewood Cliffs, NJ: Prentice-Hall, 1972.

Hermreck, L. A. A comparison of the written language of L. D. and non-L.D. elementary children using the inventory of uritten expression and spelling. Unpublished master's thesis, University of Kansas, 1979.

Hillerich, R. L. Developing written expression: How to raise - not raze - writers. Language Arts, 1979, 56, 769-777.

Hunt, K. W. Grammatical structures written at three grade levels. Research Report No. 3. Champaign, IL: National Council of Teachers of English, 1965.

Johnson, D. J., \& Myklebust, H. R. Learning disabilities: Educational principles and practices. New York: Grune \& Stratton, 1967.

Kirk, S. A., \& Johnson, G. O. Educating the retarded child. Cambridge, MA: Houghton-Mifflin, 1951.

Kraetsch, G. A. The effects of oral instructions and training on the expansion of written language. Learning Disability Quarterly. 1981, 4, 83-90.

Lerner, J. W. Learning disabilities: Theories, diagnosis, and teaching strategies (3rd ed.). Boston: Houghton-Mifflin, 1981.

Loban, W. D. The language of elementary school children: NCTE Research Report No. 1. Champaign, IL: National Council of Teachers of English, 1963.

Loban, W., Ryan, M., \& Squire, J. R. Teaching language and literature: Grades seven-twelve (2nd ed.). New York: Harcourt. Brace \& World, 1969. 
Lovitt, T. C. Applied behavior analysis and learning disabilities: Part 2. Journal of Learning Disabilities, 1975, 8, 504-518.

Maloney, K. B., \& Hopkins, B. L. The modification of structure and its relationship to subjective judgments of creative writing. Journal of Applied Behavior Analy'sis, 1973, 6, 425-433.

Mercer, C. D., \& Mercer, A. R. Teaching students with learning problems. Columbus, OH: Charles E. Merrill, 1981.

Myklebust, H. R. Development and disorders of written language: Studies of normal and exceptional children. New York: Grune \& Stratton, 1973.

Nathanson, D., Cynamon, A., \& Lehman, K. Miami: Snow poets creative writing for exceptional children. Teaching Exceptional Children, 1976, 8, 87-91.

Otto, W., McMenemy, R. A., \& Smith, R. J. Corrective and remedial teaching. Boston: Houghton-Mifflin, 1973.

Petty, W. T., \& Bowen, M. E. Slithery snakes and other aids to children's writing. New York: Appleton-Century-Crofts, 1967.

Phelps-Teraski. D., \& Phelps, T. Teaching written expression: The Phelps sentence guide program. Novato, CA: Academic Therapy, 1980.

Polloway, E. A., \& Smith, J. E. Teaching language skills to exceptional learners. Denver, CO: Love Publishing Co., 1982.

Poplin, M., Gray, R., Larsen, S.. Banikowski. A., \& Mehring, T. A comparison of components of written expression abilities in learning disabled and non-learning disabled children at three grade levels. Learning Disabilit!. Quarterly, 1980, 3, 46-53.

Rich, A., \& Nedboy, R. Hey man ... We're writing a poem: Creative writing for inner city children. Teaching Exceptional Children. 1977, 9, 92-94.

Riemer, G. How they murdered the second $R$. Toronto: W. W. Norton, 1969.

Ross, A. O. Psuchological aspects of learning disabilities and reading disorders. New York: McGraw-Hill, 1976.

Sherwin, J. S. Four problems in teaching English: $A$ critique of Research. Scranton, PA: International Textbook (for National Council of Teachers of English), 1969.

Sink, D. M. Teach-write/write-teach. Elementary English, 1975, 52. 175-177.

Smith, R. M. Clinical teaching: Methods of instruction for the retarded. New York: McGraw-Hill, 1974.

Tiedt, I. M. Input. Elementary English, 1975, 52, 163-164.

Torgeson, J. K. The role of nonspecific factors in the task performance of learning disabled children: A theoretical assessment. Journal of Learning Disabilities, 1977, 10, 27-34.

Tsimbos, L. Journal writing for non-native speakers of English. In G. Stanford (Ed.). Dealing with differences. Urbana, IL: National Council of Teachers of English, 1980.

Tway, E. Creative writing: From gimmick to goal. Elementary English, 1975, 52, 173-174.

Van Allen, R. Language experiences in communication. Boston: Houghton-Mifflin, 1976.

Van Houten, R., Morrison, E., Jarvis, R., \& MacDonald, M. The effects of explicit timing and feedback on compositional response rate in elementary school children. Journal of Applied Behavior Analy:sis, 1974, 7, 547-555.

Wallace, G., \& McLoughlin, J. Learning disabilities: Concepts and characteristics. Columbus, OH: Charles E. Merrill, 1976.

Wiig, E. H., \& Semel, E. M. Language assessment and intervention for the learning disabled. Columbus, OH: Charles E. Merrill, 1980.

Wong, B. Research and educational implications of some recent conceptualizations in learning disabilities. Learning Disability. Quarterly. 1979, 2 (3), 63-68.

\section{ADDITIONAL REFERENCES}

Affleck, J. Q., Lowenbraun, S., \& Archer, A. Teaching the mildl!! handicapped in the regular classroom (2nd ed.). Columbus, $\mathrm{OH}$ : Charles E. Merrill, 1980.
Ballard, K. D., \& Glynn, T. Behavioral self-management in story writing with elementary school children. Journal of Applied Behavior Analysis. 1975, 8, 387-398.

Blake, H., \& Spennato, N. A. The directed writing activity: A process with structure. Language Arts, 1980, 57, 317-318.

Cartwright, G. P. Written expression and spelling. In R. M. Smith (Ed.), Teacher diagnosis of educational difficulties. Columbus, OH: Charles E. Merrill, 1969.

Cordoni, B. What psychology and special education have to share with teachers of writing. Paper presented at the Conference on the Teaching of Technical Writing, Carbondale, IL, 1978. (ERIC Document Reproduction Service No. ED 172 199)

Fonosch, G. G. Attitudes of selected university faculty members toward disabled students. Doctoral dissertation, University of Nebraska, Lincoln, 1979. Dissertation Abstracts International, 1980, 40, 3696A. (University Microfilms No. 8002294, 207)

Hogan, T. P., \& Mishler, C. J. Judging the quality of students writing: Where and how. Elementary School Journal, 1979, 79. 142-146.

Loxterman, A. S. College composition and the invisible handicap. Paper presented at the 28 th annual meeting of the Conference on College Composition, Denver, 1978. (ERIC Document Reproduction Service No. ED 168 016)

McLoughlin, J. A., \& Lewis, R. B. Assessing special students. Columbus, OH: Charles E. Merrill, 1981.

Mills, P. J., \& Rodrigues, R. J. Handicapped, yes, but not in the English class. In G. Stanford (Ed.), Dealing with differences. Urbana, IL: National Council of Teachers of English, 1980.

Patton, J. R. A study of faculty attitudes toward special needs students at three community colleges in the Virginia community college sistem. Unpublished doctoral dissertation, University of Virginia, 1980.

Poteet, J. A. Informal assessment of written expression. Learning Disability Quarterly, 1980, 3 (4), 88-98.

Wallace, G., \& Larsen, S. C. Educational assessment of learning problems: Testing for teaching. Boston: Allyn \& Bacon, 1978.

Weiner, E. S. Diagnostic evaluation of writing skills. Journal of Learning Disabilities, 1980, 13, 43-48.

Wells, L. R. Writing disorders and the learning disability student in the college English classroom. Doctoral dissertation, Northwestern University, 1973. Dissertation Abstracts International, 1974, 34, 5764A-5765A. (University Microfilms No. 74-7846, p. 230)

Wiig, E. H., \& Semel, E. M. Language assessment and intervention for the learning disabled. Columbus, $\mathrm{OH}$ : Charles E. Merrill, 1980.

\section{SELECTED WRITTEN LANGUAGE INSTRUMENTS}

\section{Achievement Tests}

Durost, W. N., Bixler, H. H., Wrightstone, J. W., Prescott, G. A., \& Balow, I. H. Metropolitan achievement test. New York: Harcourt, Brace, Jovanovich, 1971.

Language components - punctuation, capitalization, and usage - are for testing with students in grades 3.5-9.5

Hammill, D. D., Brown, V. L., Larsen, S. C., \& Wiederholt, J. L. Test of adolescent language. Austin, TX: Pro-Ed, 1980.

The TOAL has two subtests related to written expression writing/vocabulary, in which the student writes a sentence using one stimulus word; and writing/grammar, in which the student must combine two sentences into one new sentence. The test is for use with ages $11-181 / 2$. 
Hieronymus, A. N., \& Lindquist, E. F. Iowa tests of basic skills. Boston: Houghton-Mifflin, 1974.

The language portion pertaining to written expression covers spelling, capitalization, punctuation, and usage. The ITBS is appropriate for grades 1-8.

Madden, R., Gardner, E. F., Rudman, H. C., Karlsen, B., \& Merwin, J. C. Stanford achievement test. New York: Psychological Corporation, 1973.

The $S A T$, with language subtests for grades 3-9.5, assesses capitalization, punctuation, and usage.

Thorpe, L. P., Lefever, D. E., \& Haslond, R. A. $S R A$ achievement series. Chicago: Science Research Associates, 1974.

For grades 2-9, the language arts component covers usage (including capitalization and punctuation) and spelling.

Tiegs, E. W., \& Clark, W. W. California achievement test. Monterey, CA: CTB/McGraw Hill, 1970.

Subtests of the $C A T$ assess language mechanics, and language usage and structure, grades 1.5-12.0.

Woodcock, R. W., \& Johnson, M. B. WoodcockJohnson psycho-educational battery. Boston: Teaching Resources, 1977.

Subtests in dictation and proofing assess skills in punctuation. capitalization, spelling, and usage.

\section{Diagnostic Tests}

Brigance, A. H. Brigance diagnostic inventory' of basic skills. Woburn, MA: Curriculum Associates, 1977.

Subtests include capitalization, punctuation, and parts of speech. The instrument is criterion-referenced, for use with grades $\mathrm{K}-7$.

Brigance, A. H. Brigance diagnostic inventory of essential skills. North Billerica, MA: Curriculum Associates, 1980.

For grades 7-12, this criterion-referenced instrument has subtests covering quality of writing, capitalization, punctuation, addressing envelopes, and letter writing.

Educational Testing Services. Sequential test of educational progress. Palo Alto, CA: Author, 1958.

Norm-referenced subtests covering organization, conventions, critical thinking, effectiveness, and appropriateness ask students to identify errors in writing specimens and select appropriate revisions; grades 4 -junior college.
Hammill, D. D., \& Larsen, S. C. Test of written language. Austin, TX: Pro-Ed, 1978.

This is a norm-referenced instrument for use with ages $81 / 2-141 / 2$. Principal subtests cover vocabulary, thematic maturity, spelling, word usage, and style, with supplemental subtests on thought units and handwriting.

Myklebust, H. Picture story language test. Los Angeles: Western Psychological Services, 1965.

Student is asked to write a story about a picture shown, and is scored on a productivity scale, syntax scale, and abstractconcrete scale. The test is norm-referenced, for use with ages 7-17.

Preparation of this manuscript was supported in part by a grant from the Office of Special Education and Rehabilitative Services, Department of Education (G00 800 0963).

\section{ALERT}

\section{NEW BOOK}

Dr. Edward A. Polloway and Dr. James E. Smith; Jr. have co-authored a book, Teaching Language Skills to Exceptional Learners, just released by Love Publishing Company. It has two major sections, the first of which examines language in general terms and the problems handicapped chidren have in developing language skills, and the second of which discusses teaching methodology and curriculum appropriate to various language skills. Topics include assessment, oral language, reading, handwriting, spelling, written expression, and organizational strategies, among other areas. The book is comprehensive, well written, and attractively presented. Books may be ordered, at $\$ 17.95$ plus $\$ 1.00$ for shipping, from: Love Publishing Company, 1777 South Bellaire Street, Denver, CO 80222. 